\title{
Microtubule-Tau Interaction as a Therapeutic Target for Alzheimer's Disease
}

\author{
Yanina Ivashko Pachima ${ }^{1} \cdot$ Liu-yao Zhou ${ }^{2} \cdot$ Peng Lei $^{2,3} \cdot$ Illana Gozes $^{1}$
}

Published online: 27 January 2016

(C) Springer Science+Business Media New York 2016

\section{Introduction}

Alzheimer's disease (AD) is an illness of progressive intellectual decline, presenting the most common age-related neurodegenerative disorder. $\mathrm{AD}$ is the most common cause of dementia and is characterized pathologically by the presence of extracellular plaques and intracellular neurofibrillary tangles (NFT) and by a selective loss of neurons and decreased synaptic density. In the middle 1980s, the major component of plaques was found to be $\beta$-amyloid (A $\beta$ ) (Glenner and Wong 1984a, b; Masters et al. 1985), generated by cleavage of amyloid precursor protein (APP) (Tanzi et al. 1987, 1992; Shoji et al. 1992). Later, tau protein was found to be the major component of NFT (Delacourte and Defossez 1986; Grundke-Iqbal et al. 1986a, b; Kosik et al. 1986; Goedert et al. 1988; Wischik et al. 1988; Lee et al. 1991; Bramblett et al. 1993). Substantial efforts have been made to find a cure or disease-modifying therapy for AD. However, whether a single target is sufficient to treat $\mathrm{AD}$ has come into question

Peng Lei

peng.lei@scu.edu.cn

Illana Gozes

igozes@post.tau.ac.il

1 Lily and Avraham Gildor Chair for the Investigation of Growth Factors, Elton Laboratory for Neuroendocrinology, Department of Human Molecular Genetics and Biochemistry, Sackler Faculty of Medicine, Adams Super Center for Brain Studies and Sagol School of Neuroscience, Tel Aviv University, Tel Aviv 69978, Israel

2 Department of Neurology, State Key Laboratory of Biotherapy, West China Hospital, Sichuan University, and Collaborative Innovation Center for Biotherapy, Sichuan 610041, China

3 Oxidation Biology Unit, Florey Institute of Neuroscience and Mental Health, The University of Melbourne, Parkville 3052, VIC, Australia since the failure of all phase III clinical trials that used A $\beta$ centric approaches (for a review, Karran et al. 2011). In this review, it is aimed to present multiple factors that may be associated with AD concentrating on microtubules (MTs)/ tau toward combinatorial therapeutics.

\section{Zinc in Alzheimer's Disease}

There is current evidence for a relative increase in intracellular zinc in vulnerable regions of the AD brain (Charton et al. 1985; Frederickson et al. 2005; Berti et al. 2015). Zinc is the second most abundant metal in the body after iron. The concentration of free zinc ions in the extracellular space of healthy brain tissue is in the range of 1 to $10 \mathrm{nM}$, and the cytosolic zinc concentration is in the picomolar range (Frederickson et al. 2005). But in the proximity of axon terminals, zinc rises to micromolar levels following release from synaptic vesicles that contain zinc in the millimolar concentration (Shen et al. 2007; Linkous et al. 2008). Synaptic zinc is involved in signal transmission/transduction across synapses and therefore modulates synaptic transmission and plasticity (Frederickson et al. 2005; Besser et al. 2009). Besides its physiological functions, zinc dyshomeostasis can contribute to neuronal and astrocytic cell death (Koh et al. 1996; Rossi et al. 2001; Bossy-Wetzel et al. 2004). It has been found that NFT and $A \beta$ plaques contain abnormally high levels of zinc at millimolar concentrations (Bush et al. 1994a, b). In addition, it has been demonstrated that $A \beta 1-40$ (a major component of $A D$ cerebral amyloid) specifically and saturably binds zinc (Bush et al. $1994 a, b)$ that could accelerate the $A \beta$ plaque formation (Bush et al. 1994a, b; Nair et al. 2010). Zinc can also interact with tau (Huang et al. 2014) and increase tau phosphorylation through activation of Erk1/2 (Yu and Fraser 2001; Harris et al. 2004; Boom et al. 2009; Kim et al. 2011) via increasing 
phosphorylation by GSK-3 $\beta$, a major tau kinase (Lei et al. 2011), on tyrosine 216 (Björkdahl et al. 2005).

\section{Microtubules and Tau}

Microtubules (MTs) are the major component of the neuronal cytoskeleton, and MT dynamics plays a key regulatory role during axon regeneration. MT stability and organization are sufficient to induce axon formation (Witte et al. 2008). The MT shaft is composed of the heterodimer protein tubulin, the major protein in the brain, that exhibits developmentally determined microheterogeneity (Gozes et al. 1975; Gozes and Littauer 1978) and is decorated by the microtubule-associated proteins (MAPs). One of the major proteins of this family is the microtubule-associated protein tau. Tau is a MT-assembly factor that appears to be enriched in neuronal axons (Tucker et al. 1988; Trojanowski et al. 1989; Lee et al. 1991). Alternative splicing around exon 10 of the tau transcript yields tau protein variants including tau protein containing either 3 or 4 MT binding repeat domains (Tau 3R or 4R), associated with dynamic and stable MT, respectively (Goedert and Jakes 1990). The healthy human brain exhibits a $1 / 1$ ratio of tau $3 R / 4 R$, and deviation from this ratio is a pathological feature of frontotemporal dementia (FTD) taupathies (Kalbfuss et al. 2001)

MT binding repeat domains are localized in the C-terminal region of tau protein, followed by a basic proline-rich region and an acidic $\mathrm{N}$-terminal region (the last does not contribute to tau-MT binding). Tau proline-rich domain includes many phosphorylation sites (Biernat et al. 1992; Augustinack et al. 2002) and can associate with SH3 domains of other proteins (Reynolds et al. 2008), including the tyrosine kinase Fyn (Lee et al. 1998). When tau was first purified from porcine brain, it was found in association with tubulin (Weingarten et al. 1975). Later, tau was shown to be a regulator of tubulin assembly in vitro (Witman et al. 1976; Cleveland et al. 1977) and in vivo (Drubin and Kirschner 1986). Tau is predominantly expressed in neuronal cells and was shown to be colocalized with tubulin in the brain stem and basal ganglia (Migheli et al. 1988). MT binding ability appears to be dependent on the three or four repeat regions of tau (Lewis et al. 1988), although a single repeat is sufficient for MT binding (Lee et al. 1989). The ability of tau to bind MTs is also dependent on its phosphorylation status (Grundke-Iqbal et al. 1986b; Bramblett et al. 1993; Harada et al. 1994; Seubert et al. 1995). Tau hyperphosphorylation reduces its affinity to MTs, which leads to the destabilization of MTs; this process has been suggested to be a loss-of-function toxicity pathway in $\mathrm{AD}$ (Hanger et al. 2009; Spires-Jones et al. 2009).

Neurons possess long, highly branched axons and dendrites, which require a precise transportation system between pre-synaptic sites and cell bodies. This long-range MT-based system is required for neuronal survival; dysfunction of this system could lead to cell death and contribute to diseases, such as AD and PD (Morfini et al. 2007; Dixit et al. 2008). Tau has been shown to interact with kinesin and dynein, both of which are integral to this process. Overexpression of tau inhibits kinesin-dependent trafficking in neuroblastoma N2a cells (Ebneth et al. 1998) and primary neuronal cells (Stamer et al. 2002). Tau can bind to the light chain of kinesin-1 (Utton et al. 2005), and an 18-amino acid sequence of tau is required for the inhibitory activity upon kinesin (LaPointe et al. 2009). On the other hand, tau also binds to the dyneinactivator complex, dynactin, which enhances its attachment to MTs (Magnani et al. 2007), and the 3-R isoform of tau is a more potent inhibitor of dynein binding to MTs (Vershinin et al. 2008). Therefore, tau differentially regulates MT-based axonal transportation. Lower levels of tau in the cell body enable kinesin to bind to MT (Dixit et al. 2008), which facilitates transportation of cargo along axons, which include tau itself (Utton et al. 2005). At the synapse, high concentrations of tau promote kinesin to release its cargo and facilitate dynein binding to MT (Dixit et al. 2008). Although this process has been well recognized, contradictory in vivo studies have shown that general rates of axonal transportation are not significantly affected by genetical overexpression or deletion of tau (Yuan et al. 2008; Vossel et al. 2010).

Since its discovery, tau has been recognized as a MT binding protein and thought to function in regulating the dynamics of MT assembly and associated axonal transport. However, the lack of overt phenotype in mice with gene deletion of tau up to 6 months of age (Roberson et al. 2007; Dawson et al. 2010; Ittner et al. 2010; Lei et al. 2012, 2014; Li et al. 2014, 2015; Ma et al. 2014) has led to the understanding that tau function is redundant. This supposition has been challenged by studies that revealed prominent motor and cognitive phenotypes in aged tau knockout mice (Lei et al. 2012, 2014; Ma et al. 2014). These observations were supported by the fact that in a Caenorhabditis elegans model, reduction in PTL-1, a tau homolog, significantly shortened the life span of the strain (Chew et al. 2013) and tau knockout Drosophila exhibited progressive neuronal degeneration (Bolkan and Kretzschmar 2014).

Tau has traditionally been considered an axonal protein; however, dendritic localization and functions of tau are evidenced by altered long-term depression (LTD) (Kimura et al. 2014) and long-term potentiation (LTP) (Ahmed et al. 2014) in tau knockout brain slices. Regan et al. showed that tau knockout mice had uninterrupted spatial learning (Regan et al. 2015) using the Barnes maze test, which confirms previous studies investigating tau knockout mice at the same age (4-5 months) in other learning paradigms (Morris Water Maze, Y-Maze, T-Maze) (Roberson et al. 2007; Ittner et al. 2010; Lei et al. 2012, 2014; Ahmed et al. 2014; Ma et al. 2014). While tau knockout mice had unimpaired learning in 
this initial setup, these knockout mice had defective reversal of this learning when the location of the escape hole was changed. In light of these findings, and compounded by the fact that tau mutations lead to various forms of non-AD dementia (Hutton et al. 1998; Spillantini et al. 1998; Goedert and Spillantini 2011), targeting tau function may be able to restore the microtubule network and prove beneficial for $A D$ and related neurodegenerations.

\section{Activity-Dependent Neuroprotective Protein, NAP, and Tau}

Using small molecules to stabilize microtubules is hypothesized to offset loss of tau function in AD. Several stabilizers were tested in animal models and showed promising results, including preventing $A \beta$ toxicity (Zempel et al. 2010), improving microtubule density (Divinski et al. 2006; Brunden et al. 2010), reducing tau phosphorylation (Vulih-Shultzman et al. 2007), and ameliorating behavioral disability (Zhang et al. 2005; Brunden et al. 2010). One of those drug candidates, NAP, showed a beneficial effect in a phase II clinical trial in amnestic mild cognitive impaired patients preceding AD (Gozes et al. 2009; Morimoto et al. 2013; Magen and Gozes 2014).

NAP (NAPVSIPQ), an eight-amino-acid peptide, identified as the smallest active element of activity-dependent neuroprotective protein (ADNP) (Bassan et al. 1999; Zamostiano et al. 2001). ADNP is vital for brain formation (Pinhasov et al. 2003; Mandel et al. 2007) and neurite outgrowth in vitro (Mandel et al. 2008). Furthermore, ADNP also provides glial protection (Pascual and Guerri 2007; Vulih-Shultzman et al. 2007). ADNP is a member of the SWI/SNF chromatin remodeling complex (Mandel and Gozes 2007), which is associated with transcription and splicing (Batsche et al. 2006). ADNP expression was previously shown to be correlated with tau 3R expression (Schirer et al. 2014). We also showed a direct interaction of ADNP with protein associated splicing factor (PSF) (Schirer et al. 2014), which was found to associate with the SWI/SNF-like complex (Ito et al. 2008) and also with tau splicing. PSF suppresses tau exon 10 inclusion by interacting with a stem-loop structure downstream of exon 10 (Ray et al. 2011). Moreover, Adnp ${ }^{+/-}$mice exhibit tauopathy (significant increase in phosphorylated tau and tangle-like structures), reduced neuronal survival, and age-driven neurodegeneration and behavioral deficits (Vulih-Shultzman et al. 2007).

NAP protects against ADNP deficiencies (VulihShultzman et al. 2007) and exhibits potent neuroprotective activities against a number of toxic insults, including several relevant to neurodegenerative diseases such as the $A \beta$ peptide (Bassan et al. 1999; Gozes et al. 2008), excitotoxicity (Bassan et al. 1999), oxidative stress (Steingart et al. 2000), and oxygen glucose deprivation-associated apoptosis (Zemlyak et al.
2009), which is paralleled by protection against tau hyperphosphorylation (Idan-Feldman et al. 2012). NAP was further identified as a neurotrophic factor, stimulating neurite outgrowth and dendrite formation (Smith-Swintosky et al. 2005; Oz et al. 2012, 2014). These results were corroborated by other investigators worldwide (Pascual and Guerri 2007; Chen and Charness 2008; Jehle et al. 2008).

High zinc concentration (from $200 \mu \mathrm{M}$ and more) caused significant increase in cell death (Oz et al. 2012). These results are compatible with previous publications reporting that an increase in the intracellular free zinc is neurotoxic and its accumulation may contribute to neuronal injury in several diseases, including neurodegenerative conditions such as AD. Moreover, aberrant zinc metal homeostasis has been reported in the brains of $\mathrm{AD}$ patients and this metal could contribute to the development of the lesions (Religa et al. 2006). However, NAP treatment, added together with zinc, significantly increased cell viability under zinc toxic condition (Divinski et al. 2004, 2006; Oz et al. 2012, 2014) and that proved again its neuroprotective ability (Bassan et al. 1999; Wilkemeyer et al. 2003; Busciglio et al. 2007; Gozes and Divinski 2007; Pascual and Guerri 2007; Gozes et al. 2008).

Zinc activity on MTs may contribute to the development of tau pathology (Pei et al. 2006; Boom et al. 2009). Zinc toxicity decreased tubulin and tau content in the polymerized fraction of MTs in the PC12 cell line, and NAP treatment protected against tubulin and tau loss from assembled MTs in the PC12 cells in the face of the toxic agent-zinc (Oz et al. 2012). Similarly, in a Drosophila model of tauopathy in which abnormal human tau mediates neuronal dysfunction, NAP enhanced tau-MT interaction (Quraishe et al. 2013).

Binding of tau to MTs is regulated through phosphorylation, and increased GSK-3 $\beta$ activity reduces the association of tau with MT (Lovestone et al. 1999; Leroy et al. 2000). We (Vulih-Shultzman et al. 2007) demonstrated a NAP-dependent reduction in activated GSK-3 $\beta$ that is associated with the pathological hyperphosphorylation of tau. In this respect, ADNP deficiency resulted in increased GSK-3 $\beta$ active form, tau hyperphosphorylation, and neurofibrillary tangle-like structure formation, which have been prevented by NAP treatment. Corroborating results showed that NAP requires Fyn kinase for activity (Chen and Charness 2008). NAP requires the neuronal marker, tubulin $\beta 3$ for MT interactions in neurons (Divinski et al. 2006; Sudo and Baas 2011), and NAP treatment enhances tubulin $\beta 3$ expression (Oz et al. 2012). ADNP deficiency was associated with deregulation of tubulin expression, in a developmental and sex-dependent manner, in vivo (Amram et al. 2016), and in depletion of the axonal marker MAP2, in vitro (Mandel et al. 2008), while NAP increased MAP2 expression (Smith-Swintosky et al. 2005). Together, these results suggest the NAP can serve as a multi-targeting compound to treat $\mathrm{AD}$. 


\section{Mechanism and Future Horizons}

Our most recent work (Gozes laboratory) identified the SIP (Ser-Ile-Pro) motif in NAP (NAPVSIPQ) as the NAP binding site for MT fortification, namely, binding to the MT end binding proteins EB1 and EB3 (Oz et al. 2014). NAP enhances ADNP interaction with EB3 and also with a key component of the autophagy process, the initiator of the autophagosome formation, MT-associated protein 1 light chain 3 (Merenlender-Wagner et al. 2015). Thus, NAP protects MTs and the autophagy process (Esteves et al. 2014) inhibiting apoptosis. Importantly, NAP protects MT-dependent axonal transport (Jouroukhin et al. 2013; Quraishe et al. 2013), with postmortem AD brains showing depletion in MTs (Cash et al. 2003). Capitulating on the NAP target, we have designed SKIP (Ser-Lys-Ile-Pro) and shown that it mimics NAP protection, as well as protects ADNP-deficient impairment in axonal transport (Amram et al. 2016). Together with new diagnostic tools, such as changes in blood ADNP in parallel to brain cognitive decline (Malishkevich et al. 2015), this and other pipeline products (Shiryaev et al. 2011; Gozes et al. 2014a, b) are ready for future development, at the basic mechanistic understanding and at the clinical frontiers.

Acknowledgments The Gozes laboratory is supported by the AMN Foundation, Israel Science Foundation, Adams Super Center for Brain Studies, the Edersheim Levie-Gitter Institute for Functional Brain Imaging, the Diana and Zelman Elton (Elbaum) Laboratory for Molecular Neuroendocrinology, and the Lily and Avraham Gildor Chair for the Investigation of Growth Factors at Tel Aviv University. Gozes is a Humboldt Award Recipient. This review is in partial fulfillment of graduate studies requirements for Yanina Ivashko Pachima, a Joseph Sagol fellowship recipient, at the Miriam and Sheldon G. Adelson Graduate School of Medicine, Sackler Faculty of Medicine, Tel Aviv University. NAP and SKIP are under patent protection and under term sheet agreement to Coronis Partners (IG conflict of interest). We thank Shlomo Sragovich, at the Miriam and Sheldon G. Adelson Graduate School of Medicine, Sackler Faculty of Medicine, for his input. The Lei laboratory is supported by funds from National Natural Science Foundation of China (81571236). P. Lei was supported by the "The Thousand Talents Plan" Young Professional Program and the "The Thousand Talents Plan" of Sichuan Province.

\section{References}

Ahmed T, Van der Jeugd A, Blum D, Galas MC, D'Hooge R, Buee L, Balschun D (2014) Cognition and hippocampal synaptic plasticity in mice with a homozygous tau deletion. Neurobiol Aging 35:2474 2478

Amram N, Hacohen Kleiman G, Sragovisch S, Malishkevich A, Katz J, Touloumi O, Lagoudaki R, Grigoriadis N, Giladi E, Yeheskel A, Pasmanik-Chor M, Jouroukhin Y, Gozes I (2016) Sexual divergence in microtubule function: the novel intranasal microtubule targeting SKIP normalizes axonal transport and enhances memory. Mol Psychiatry. doi:10.1038/mp.2015.208
Augustinack JC, Schneider A, Mandelkow EM, Hyman BT (2002) Specific tau phosphorylation sites correlate with severity of neuronal cytopathology in Alzheimer's disease. Acta Neuropathol 103:26-35

Bassan M, Zamostiano R, Davidson A, Pinhasov A, Giladi E, Perl O, Bassan H, Blat C, Gibney G, Glazner G, Brenneman DE, Gozes I (1999) Complete sequence of a novel protein containing a femtomolar-activity-dependent neuroprotective peptide. J Neurochem 72:1283-1293

Batsche E, Yaniv M, Muchardt C (2006) The human SWI/SNF subunit $\mathrm{Brm}$ is a regulator of alternative splicing. Nat Struct Mol Biol 13:2229

Berti V, Murray J, Davies M, Spector N, Tsui WH, Li Y, Williams S, Pirraglia E, Vallabhajosula S, McHugh P, Pupi A, de Leon MJ, Mosconi L (2015) Nutrient patterns and brain biomarkers of Alzheimer's disease in cognitively normal individuals. J Nutr Health Aging 19:413-423

Besser L, Chorin E, Sekler I, Silverman WF, Atkin S, Russell JT, Hershfinkel M (2009) Synaptically released zinc triggers metabotropic signaling via a zinc-sensing receptor in the hippocampus. $\mathrm{J}$ Neurosci: Off J Soc Neurosci 29:2890-2901

Biernat J, Mandelkow EM, Schroter C, Lichtenberg-Kraag B, Steiner B, Berling B, Meyer H, Mercken M, Vandermeeren A, Goedert M et al (1992) The switch of tau protein to an Alzheimer-like state includes the phosphorylation of two serine-proline motifs upstream of the microtubule binding region. EMBO J 11:1593-1597

Björkdahl C, Sjögren MJ, Winblad B, Pei J-J (2005) Zinc induces neurofilament phosphorylation independent of p70 S6 kinase in N2a cells. Neuroreport 16:591-595

Bolkan BJ, Kretzschmar D (2014) Loss of Tau results in defects in photoreceptor development and progressive neuronal degeneration in Drosophila. Dev Neurobiol 74:1210-1225

Boom A, Authelet M, Dedecker R, Frederick C, Van Heurck R, Daubie V, Leroy K, Pochet R, Brion JP (2009) Bimodal modulation of tau protein phosphorylation and conformation by extracellular $\mathrm{Zn} 2+$ in human-tau transfected cells. Biochim Biophys Acta 1793:10581067

Bossy-Wetzel E, Talantova MV, Lee WD, Scholzke MN, Harrop A, Mathews E, Gotz T, Han J, Ellisman MH, Perkins GA, Lipton SA (2004) Crosstalk between nitric oxide and zinc pathways to neuronal cell death involving mitochondrial dysfunction and p38-activated $\mathrm{K}+$ channels. Neuron 41:351-365

Bramblett GT, Goedert M, Jakes R, Merrick SE, Trojanowski JQ, Lee VM (1993) Abnormal tau phosphorylation at Ser396 in Alzheimer's disease recapitulates development and contributes to reduced microtubule binding. Neuron 10:1089-1099

Brunden KR, Zhang B, Carroll J, Yao Y, Potuzak JS, Hogan AM, Iba M, James MJ, Xie SX, Ballatore C, Smith AB 3rd, Lee VM, Trojanowski JQ (2010) Epothilone D improves microtubule density, axonal integrity, and cognition in a transgenic mouse model of tauopathy. J Neurosci 30:13861-13866

Busciglio J, Pelsman A, Helguera P, Ashur-Fabian O, Pinhasov A, Brenneman DE, Gozes I (2007) NAP and ADNF-9 protect normal and Down's syndrome cortical neurons from oxidative damage and apoptosis. Curr Pharm Des 13:1091-1098

Bush AI, Pettingell WH Jr, de Paradis M, Tanzi RE, Wasco W (1994a) The amyloid beta-protein precursor and its mammalian homologues. Evidence for a zinc-modulated heparin-binding superfamily. J Biol Chem 269:26618-26621

Bush AI, Pettingell WH, Multhaup G, de Paradis M, Vonsattel JP, Gusella JF, Beyreuther K, Masters CL, Tanzi RE (1994b) Rapid induction of Alzheimer A beta amyloid formation by zinc. Science 265:1464 1467

Cash AD, Aliev G, Siedlak SL, Nunomura A, Fujioka H, Zhu X, Raina AK, Vinters HV, Tabaton M, Johnson AB, Paula-Barbosa M, Avila J, Jones PK, Castellani RJ, Smith MA, Perry G (2003) Microtubule 
reduction in Alzheimer's disease and aging is independent of tau filament formation. Am J Pathol 162:1623-1627

Charton G, Rovira C, Ben-Ari Y, Leviel V (1985) Spontaneous and evoked release of endogenous $\mathrm{Zn} 2+$ in the hippocampal mossy fiber zone of the rat in situ. Exp Brain Res 58:202-205

Chen S, Charness ME (2008) Ethanol inhibits neuronal differentiation by disrupting activity-dependent neuroprotective protein signaling. Proc Natl Acad Sci U S A 105:19962-19967

Chew YL, Fan X, Gotz J, Nicholas HR (2013) PTL-1 regulates neuronal integrity and lifespan in C. elegans. J Cell Sci 126:2079-2091

Cleveland DW, Hwo SY, Kirschner MW (1977) Purification of tau, a microtubule-associated protein that induces assembly of microtubules from purified tubulin. J Mol Biol 116:207-225

Dawson HN, Cantillana V, Jansen M, Wang HY, Vitek MP, Wilcock DM, Lynch JR, Laskowitz DT (2010) Loss of tau elicits axonal degeneration in a mouse model of Alzheimer's disease. Neuroscience 169: 516-531

Delacourte A, Defossez A (1986) Alzheimer's disease: Tau proteins, the promoting factors of microtubule assembly, are major components of paired helical filaments. J Neurol Sci 76:173-186

Divinski I, Mittelman L, Gozes I (2004) A femtomolar acting octapeptide interacts with tubulin and protects astrocytes against zinc intoxication. J Biol Chem 279:28531-28538

Divinski I, Holtser-Cochav M, Vulih-Schultzman I, Steingart RA, Gozes I (2006) Peptide neuroprotection through specific interaction with brain tubulin. J Neurochem 98:973-984

Dixit R, Ross JL, Goldman YE, Holzbaur ELF (2008) Differential regulation of dynein and kinesin motor proteins by tau. Science 319 : 1086-1089

Drubin DG, Kirschner MW (1986) Tau protein function in living cells. J Cell Biol 103:2739-2746

Ebneth A, Godemann R, Stamer K, Illenberger S, Trinczek B, Mandelkow E (1998) Overexpression of tau protein inhibits kinesin-dependent trafficking of vesicles, mitochondria, and endoplasmic reticulum: implications for Alzheimer's disease. J Cell Biol 143:777-794

Esteves AR, Gozes I, Cardoso SM (2014) The rescue of microtubuledependent traffic recovers mitochondrial function in Parkinson's disease. Biochim Biophys Acta 1842:7-21

Frederickson CJ, Koh JY, Bush AI (2005) The neurobiology of zinc in health and disease. Nat Rev Neurosci 6:449-462

Glenner GG, Wong CW (1984a) Alzheimer's disease and Down's syndrome: sharing of a unique cerebrovascular amyloid fibril protein. Biochem Biophys Res Commun 122:1131-1135

Glenner GG, Wong CW (1984b) Alzheimer's disease: initial report of the purification and characterization of a novel cerebrovascular amyloid protein. Biochem Biophys Res Commun 120:885-890

Goedert M, Jakes R (1990) Expression of separate isoforms of human tau protein: correlation with the tau pattern in brain and effects on tubulin polymerization. EMBO J 9:4225-4230

Goedert M, Spillantini MG (2011) Pathogenesis of the tauopathies. J Mol Neurosci 45:425-431

Goedert M, Wischik CM, Crowther RA, Walker JE, Klug A (1988) Cloning and sequencing of the cDNA encoding a core protein of the paired helical filament of Alzheimer disease: identification as the microtubule-associated protein tau. Proc Natl Acad Sci U S A 85: 4051-4055

Gozes I, Divinski I (2007) NAP, a neuroprotective drug candidate in clinical trials, stimulates microtubule assembly in the living cell. Curr Alzheim Res 4:507-509

Gozes I, Littauer UZ (1978) Tubulin microheterogeneity increases with rat brain maturation. Nature 276:411-413

Gozes I, Schmitt H, Littauer UZ (1975) Translation in vitro of rat brain messenger RNA coding for tubulin and actin. Proc Natl Acad Sci U S A 72:701-705
Gozes I, Divinski I, Piltzer I (2008) NAP and D-SAL: neuroprotection against the beta amyloid peptide (1-42). BMC Neurosci 9(Suppl 3): S3

Gozes I, Stewart A, Morimoto B, Fox A, Sutherland K, Schmeche D (2009) Addressing Alzheimer's disease tangles: from NAP to AL108. Curr Alzheim Res 6:455-460

Gozes I, Iram T, Maryanovsky E, Arviv C, Rozenberg L, Schirer Y, Giladi E, Furman-Assaf S (2014a) Novel tubulin and tau neuroprotective fragments sharing structural similarities with the drug candidate NAP (Davuentide). J Alzheimers Dis 40(Suppl 1):S23-36

Gozes I, Schirer Y, Idan-Feldman A, David M, Furman-Assaf S (2014b) NAP alpha-aminoisobutyric acid (IsoNAP). J Mol Neurosci 52:1-9

Grundke-Iqbal I, Iqbal K, Quinlan M, Tung YC, Zaidi MS, Wisniewski HM (1986a) Microtubule-associated protein tau. A component of Alzheimer paired helical filaments. J Biol Chem 261:6084-6089

Grundke-Iqbal I, Iqbal K, Tung YC, Quinlan M, Wisniewski HM, Binder LI (1986b) Abnormal phosphorylation of the microtubuleassociated protein tau (tau) in Alzheimer cytoskeletal pathology. Proc Natl Acad Sci U S A 83:4913-4917

Hanger DP, Anderton BH, Noble WJ (2009) Tau phosphorylation: the therapeutic challenge for neurodegenerative disease. Trends Mol Med 15:112-119

Harada A, Oguchi K, Okabe S, Kuno J, Terada S, Ohshima T, SatoYoshitake R, Takei Y, Noda T, Hirokawa N (1994) Altered microtubule organization in small-calibre axons of mice lacking tau protein. Nature 369:488-491

Harris FM, Brecht WJ, Xu Q, Mahley RW, Huang Y (2004) Increased tau phosphorylation in apolipoprotein E4 transgenic mice is associated with activation of extracellular signal-regulated kinase: modulation by zinc. J Biol Chem 279:44795-44801

Huang Y, Wu Z, Cao Y, Lang M, Lu B, Zhou B (2014) Zinc binding directly regulates tau toxicity independent of tau hyperphosphorylation. Cell reports

Hutton M, Lendon CL, Rizzu P, Baker M, Froelich S, Houlden H, Pickering-Brown S, Chakraverty S, Isaacs A, Grover A, Hackett J, Adamson J, Lincoln S, Dickson D, Davies P, Petersen RC, Stevens M, de Graaff E, Wauters E, van Baren J, Hillebrand M, Joosse M, Kwon JM, Nowotny P, Che LK, Norton J, Morris JC, Reed LA, Trojanowski J, Basun H, Lannfelt L, Neystat M, Fahn S, Dark F, Tannenberg T, Dodd PR, Hayward N, Kwok JB, Schofield PR, Andreadis A, Snowden J, Craufurd D, Neary D, Owen F, Oostra BA, Hardy J, Goate A, van Swieten J, Mann D, Lynch T, Heutink P (1998) Association of missense and 5'-splice-site mutations in tau with the inherited dementia FTDP-17. Nature 393:702-705

Idan-Feldman A, Ostritsky R, Gozes I (2012) Tau and caspase 3 as targets for neuroprotection. Int J Alzheimers Dis 2012:493670

Ito T, Watanabe H, Yamamichi N, Kondo S, Tando T, Haraguchi T, Mizutani T, Sakurai K, Fujita S, Izumi T, Isobe T, Iba H (2008) Brm transactivates the telomerase reverse transcriptase (TERT) gene and modulates the splicing patterns of its transcripts in concert with p54(nrb). Biochem J 411:201-209

Ittner LM, Ke YD, Delerue F, Bi M, Gladbach A, van Eersel J, Wolfing H, Chieng BC, Christie MJ, Napier IA, Eckert A, Staufenbiel M, Hardeman E, Gotz J (2010) Dendritic function of tau mediates amyloid-beta toxicity in Alzheimer's disease mouse models. Cell 142:387-397

Jehle T, Dimitriu C, Auer S, Knoth R, Vidal-Sanz M, Gozes I, Lagreze WA (2008) The neuropeptide NAP provides neuroprotection against retinal ganglion cell damage after retinal ischemia and optic nerve crush. Graefes Arch Clin Exp Ophthalmol 246:1255-1263

Jouroukhin Y, Ostritsky R, Assaf Y, Pelled G, Giladi E, Gozes I (2013) NAP (davunetide) modifies disease progression in a mouse model of severe neurodegeneration: protection against impairments in axonal transport. Neurobiol Dis 56:79-94 
Kalbfuss B, Mabon SA, Misteli T (2001) Correction of alternative splicing of tau in frontotemporal dementia and parkinsonism linked to chromosome 17. J Biol Chem 276:42986-42993

Karran E, Mercken M, De Strooper B (2011) The amyloid cascade hypothesis for Alzheimer's disease: an appraisal for the development of therapeutics. Nat Rev Drug Discov 10:698-712

Kim I, Park EJ, Seo J, Ko SJ, Lee J, Kim CH (2011) Zinc stimulates tau S214 phosphorylation by the activation of Raf/mitogen-activated protein kinase-kinase/extracellular signal-regulated kinase pathway. Neuroreport 22:839-844

Kimura T, Whitcomb DJ, Jo J, Regan P, Piers T, Heo S, Brown C, Hashikawa T, Murayama M, Seok H, Sotiropoulos I, Kim E, Collingridge GL, Takashima A, Cho K (2014) Microtubuleassociated protein tau is essential for long-term depression in the hippocampus. Philos Trans R Soc Lond Ser B Biol Sci 369: 20130144

Koh JY, Suh SW, Gwag BJ, He YY, Hsu CY, Choi DW (1996) The role of zinc in selective neuronal death after transient global cerebral ischemia. Science 272:1013-1016

Kosik KS, Joachim CL, Selkoe DJ (1986) Microtubule-associated protein tau (tau) is a major antigenic component of paired helical filaments in Alzheimer disease. Proc Natl Acad Sci U S A 83:4044-4048

LaPointe NE, Morfini G, Pigino G, Gaisina IN, Kozikowski AP, Binder LI, Brady ST (2009) The amino terminus of tau inhibits kinesindependent axonal transport: implications for filament toxicity. J Neurosci Res 87:440-451

Lee G, Neve RL, Kosik KS (1989) The microtubule binding domain of tau protein. Neuron 2:1615-1624

Lee VM, Balin BJ, Otvos L Jr, Trojanowski JQ (1991) A68: a major subunit of paired helical filaments and derivatized forms of normal Tau. Science 251:675-678

Lee G, Newman ST, Gard DL, Band H, Panchamoorthy G (1998) Tau interacts with src-family non-receptor tyrosine kinases. J Cell Sci 111(Pt 21):3167-3177

Lei P, Ayton S, Bush AI, Adlard PA (2011) GSK-3 in neurodegenerative diseases. Int J Alzheim Dis 2011:189246

Lei P, Ayton S, Finkelstein DI, Spoerri L, Ciccotosto GD, Wright DK, Wong BXW, Adlard PA, Cherny RA, Lam LQ, Roberts BR, Volitakis I, Egan GF, Mclean CA, Cappai R, Duce JA, Bush AI (2012) Tau deficiency induces parkinsonism with dementia by impairing APP-mediated iron export. Nat Med 18:291-295

Lei P, Ayton S, Moon S, Zhang Q, Volitakis I, Finkelstein DI, Bush AI (2014) Motor and cognitive deficits in aged tau knockout mice in two background strains. Mol Neurodegener 9:29

Leroy K, Menu R, Conreur JL, Dayanandan R, Lovestone S, Anderton $\mathrm{BH}$, Brion JP (2000) The function of the microtubule-associated protein tau is variably modulated by graded changes in glycogen synthase kinase-3beta activity. FEBS Lett 465:34-38

Lewis SA, Wang DH, Cowan NJ (1988) Microtubule-associated protein MAP2 shares a microtubule binding motif with tau protein. Science 242:936-939

Li Z, Hall AM, Kelinske M, Roberson ED (2014) Seizure resistance without parkinsonism in aged mice after tau reduction. Neurobiol Aging 35:2617-2624

Li X, Lei P, Tuo Q, Ayton S, Li QX, Moon S, Volitakis I, Liu R, Masters CL, Finkelstein DI, Bush AI (2015) Enduring elevations of hippocampal amyloid precursor protein and iron are features of betaamyloid toxicity and are mediated by tau. Neurotherapeutics 12 : 862-873

Linkous DH, Flinn JM, Koh JY, Lanzirotti A, Bertsch PM, Jones BF, Giblin LJ, Frederickson CJ (2008) Evidence that the ZNT3 protein controls the total amount of elemental zinc in synaptic vesicles. J Histochem Cytochem 56:3-6

Lovestone S, Davis DR, Webster MT, Kaech S, Brion JP, Matus A, Anderton BH (1999) Lithium reduces tau phosphorylation: effects in living cells and in neurons at therapeutic concentrations. Biol Psychiatry 45:995-1003

Ma QL, Zuo X, Yang F, Ubeda OJ, Gant DJ, Alaverdyan M, Kiosea NC, Nazari S, Chen PP, Nothias F, Chan P, Teng E, Frautschy SA, Cole GM (2014) Loss of MAP function leads to hippocampal synapse loss and deficits in the Morris Water Maze with aging. J Neurosci 34:7124-7136

Magen I, Gozes I (2014) Davunetide: peptide therapeutic in neurological disorders. Curr Med Chem 21:2591-2598

Magnani E, Fan J, Gasparini L, Golding M, Williams M, Schiavo G, Goedert M, Amos LA, Spillantini MG (2007) Interaction of tau protein with the dynactin complex. Embo J 26:4546-4554

Malishkevich A, Marshall GA, Schultz AP, Sperling RA, Aharon-Peretz J, Gozes I (2015) Blood-borne activity-dependent neuroprotective protein (ADNP) is correlated with premorbid intelligence, clinical stage, and Alzheimer's disease biomarkers. J Alzheimers Dis

Mandel S, Gozes I (2007) Activity-dependent neuroprotective protein constitutes a novel element in the SWI/SNF chromatin remodeling complex. J Biol Chem 282:34448-34456

Mandel S, Rechavi G, Gozes I (2007) Activity-dependent neuroprotective protein (ADNP) differentially interacts with chromatin to regulate genes essential for embryogenesis. Dev Biol 303:814-824

Mandel S, Spivak-Pohis I, Gozes I (2008) ADNP differential nucleus/ cytoplasm localization in neurons suggests multiple roles in neuronal differentiation and maintenance. J Mol Neurosci 35:127-141

Masters CL, Simms G, Weinman NA, Multhaup G, McDonald BL, Beyreuther K (1985) Amyloid plaque core protein in Alzheimer disease and Down syndrome. Proc Natl Acad Sci U S A 82:42454249

Merenlender-Wagner A, Malishkevich A, Shemer Z, Udawela M, Gibbons A, Scarr E, Dean B, Levine J, Agam G, Gozes I (2015) Autophagy has a key role in the pathophysiology of schizophrenia. Mol Psychiatry 20:126-132

Migheli A, Butler M, Brown KW, Shelanski ML (1988) Light and electron microscope localization of the microtubule-associated tau protein in rat brain. J Neurosci 8:1846-1851

Morfini GA, Pigino G, Opalach K, Serulle Y, Moreira JE, Sugimori M, Llinás RR, Brady ST (2007) 1-Methyl-4-phenylpyridinium affects fast axonal transport by activation of caspase and protein kinase $\mathrm{C}$. Proc Natl Acad Sci U S A 104:2442-2447

Morimoto BH, Schmechel D, Hirman J, Blackwell A, Keith J, Gold M (2013) A double-blind, placebo-controlled, ascending-dose, randomized study to evaluate the safety, tolerability and effects on cognition of AL-108 after 12 weeks of intranasal administration in subjects with mild cognitive impairment. Dement Geriatr Cogn Disord 35:325-336

Nair NG, Perry G, Smith MA, Reddy VP (2010) NMR studies of zinc, copper, and iron binding to histidine, the principal metal ion complexing site of amyloid-beta peptide. J Alzheimers Dis 20:5766

Oz S, Ivashko-Pachima Y, Gozes I (2012) The ADNP derived peptide, NAP modulates the tubulin pool: implication for neurotrophic and neuroprotective activities. PLoS ONE 7, e51458

Oz S, Kapitansky O, Ivashco-Pachima Y, Malishkevich A, Giladi E, Skalka N, Rosin-Arbesfeld R, Mittelman L, Segev O, Hirsch JA, Gozes I (2014) The NAP motif of activity-dependent neuroprotective protein (ADNP) regulates dendritic spines through microtubule end binding proteins. Mol Psychiatry 19:1115-1124

Pascual M, Guerri C (2007) The peptide NAP promotes neuronal growth and differentiation through extracellular signal-regulated protein kinase and Akt pathways, and protects neurons co-cultured with astrocytes damaged by ethanol. J Neurochem 103:557-568

Pei JJ, An WL, Zhou XW, Nishimura T, Norberg J, Benedikz E, Gotz J, Winblad B (2006) P70 S6 kinase mediates tau phosphorylation and synthesis. FEBS Lett 580:107-114 
Pinhasov A, Mandel S, Torchinsky A, Giladi E, Pittel Z, Goldsweig AM, Servoss SJ, Brenneman DE, Gozes I (2003) Activity-dependent neuroprotective protein: a novel gene essential for brain formation. Brain Res Dev Brain Res 144:83-90

Quraishe S, Cowan CM, Mudher A (2013) NAP (davunetide) rescues neuronal dysfunction in a Drosophila model of tauopathy. Mol Psychiatry 18:834-842

Ray P, Kar A, Fushimi K, Havlioglu N, Chen X, Wu JY (2011) PSF suppresses tau exon 10 inclusion by interacting with a stem-loop structure downstream of exon 10. J Mol Neurosci 45:453-466

Regan P, Piers T, Yi JH, Kim DH, Huh S, Park SJ, Ryu JH, Whitcomb DJ, Cho K (2015) Tau phosphorylation at serine 396 residue is required for hippocampal LTD. J Neurosci 35:4804-4812

Religa D, Strozyk D, Cherny RA, Volitakis I, Haroutunian V, Winblad B, Naslund J, Bush AI (2006) Elevated cortical zinc in Alzheimer disease. Neurology 67:69-75

Reynolds CH, Garwood CJ, Wray S, Price C, Kellie S, Perera T, Zvelebil M, Yang A, Sheppard PW, Varndell IM, Hanger DP, Anderton BH (2008) Phosphorylation regulates tau interactions with Src homology 3 domains of phosphatidylinositol 3-kinase, phospholipase Cgamma1, Grb2, and Src family kinases. J Biol Chem 283: $18177-18186$

Roberson ED, Scearce-Levie K, Palop JJ, Yan F, Cheng IH, Wu T, Gerstein H, Yu G-Q, Mucke L (2007) Reducing endogenous tau ameliorates amyloid beta-induced deficits in an Alzheimer's disease mouse model. Science 316:750-754

Rossi L, De Martino A, Marchese E, Piccirilli S, Rotilio G, Ciriolo MR (2001) Neurodegeneration in the animal model of Menkes' disease involves Bcl-2-linked apoptosis. Neuroscience 103:181-188

Schirer Y, Malishkevich A, Ophir Y, Lewis J, Giladi E, Gozes I (2014) Novel marker for the onset of frontotemporal dementia: early increase in activity-dependent neuroprotective protein (ADNP) in the face of Tau mutation. PLoS ONE 9, e87383

Seubert P, Mawal-Dewan M, Barbour R, Jakes R, Goedert M, Johnson GVW, Litersky JM, Schenk D, Lieberburg I, Trojanowski JQ (1995) Detection of phosphorylated Ser262 in fetal tau, adult tau, and paired helical filament tau. J Biol Chem 270:18917-18922

Shen H, Zhang Y, Xu J, Long J, Qin H, Liu F, Guo J (2007) Zinc distribution and expression pattern of ZnT3 in mouse brain. Biol Trace Elem Res 119:166-174

Shiryaev N, Pikman R, Giladi E, Gozes I (2011) Protection against tauopathy by the drug candidates NAP (davunetide) and D-SAL: biochemical, cellular and behavioral aspects. Curr Pharm Des 17: 2603-2612

Shoji M, Golde TE, Ghiso J, Cheung TT, Estus S, Shaffer LM, Cai XD, McKay DM, Tintner R, Frangione B (1992) Production of the Alzheimer amyloid beta protein by normal proteolytic processing. Science 258:126-129

Smith-Swintosky VL, Gozes I, Brenneman DE, D'Andrea MR, PlataSalaman CR (2005) Activity-dependent neurotrophic factor-9 and NAP promote neurite outgrowth in rat hippocampal and cortical cultures. J Mol Neurosci 25:225-238

Spillantini MG, Murrell JR, Goedert M, Farlow MR, Klug A, Ghetti B (1998) Mutation in the tau gene in familial multiple system tauopathy with presenile dementia. Proc Natl Acad Sci U S A 95: $7737-7741$

Spires-Jones TL, Stoothoff WH, de Calignon A, Jones PB, Hyman BT (2009) Tau pathophysiology in neurodegeneration: a tangled issue. Trends Neurosci 32:150-159

Stamer K, Vogel R, Thies E, Mandelkow E, Mandelkow E-M (2002) Tau blocks traffic of organelles, neurofilaments, and APP vesicles in neurons and enhances oxidative stress. J Cell Biol 156:1051-1063

Steingart RA, Solomon B, Brenneman DE, Fridkin M, Gozes I (2000) VIP and peptides related to activity-dependent neurotrophic factor protect PC12 cells against oxidative stress. J Mol Neurosci 15:137145

Sudo H, Baas PW (2011) Strategies for diminishing katanin-based loss of microtubules in tauopathic neurodegenerative diseases. Hum Mol Genet 20:763-778

Tanzi RE, Gusella JF, Watkins PC, Bruns GA, St George-Hyslop P, Van Keuren ML, Patterson D, Pagan S, Kurnit DM, Neve RL (1987) Amyloid beta protein gene: cDNA, mRNA distribution, and genetic linkage near the Alzheimer locus. Science 235:880-884

Tanzi RE, Vaula G, Romano DM, Mortilla M, Huang TL, Tupler RG, Wasco W, Hyman BT, Haines JL, Jenkins BJ et al (1992) Assessment of amyloid beta-protein precursor gene mutations in a large set of familial and sporadic Alzheimer disease cases. Am J Hum Genet 51:273-282

Trojanowski JQ, Schuck T, Schmidt ML, Lee VM (1989) Distribution of tau proteins in the normal human central and peripheral nervous system. J Histochem Cytochem 37:209-215

Tucker RP, Binder LI, Matus AI (1988) Neuronal microtubule-associated proteins in the embryonic avian spinal cord. J Comp Neurol 271:44 55

Utton MA, Noble WJ, Hill JE, Anderton BH, Hanger DP (2005) Molecular motors implicated in the axonal transport of tau and alpha-synuclein. J Cell Sci 118:4645-4654

Vershinin M, Xu J, Razafsky DS, King SJ, Gross SP (2008) Tuning microtubule-based transport through filamentous MAPs: the problem of dynein. Traffic (Copenhagen, Denmark) 9:882-892

Vossel KA, Zhang K, Brodbeck J, Daub AC, Sharma P, Finkbeiner S, Cui B, Mucke L (2010) Tau reduction prevents A $\{$ beta $\}$-induced defects in axonal transport. Science 330:198

Vulih-Shultzman I, Pinhasov A, Mandel S, Grigoriadis N, Touloumi O, Pittel Z, Gozes I (2007) Activity-dependent neuroprotective protein snippet NAP reduces tau hyperphosphorylation and enhances learning in a novel transgenic mouse model. J Pharmacol Exp Ther 323: 438-449

Weingarten MD, Lockwood AH, Hwo SY, Kirschner MW (1975) A protein factor essential for microtubule assembly. Proc Natl Acad Sci U S A 72:1858-1862

Wilkemeyer MF, Chen SY, Menkari CE, Brenneman DE, Sulik KK, Charness ME (2003) Differential effects of ethanol antagonism and neuroprotection in peptide fragment NAPVSIPQ prevention of ethanol-induced developmental toxicity. Proc Natl Acad Sci U S A 100:8543-8548

Wischik CM, Novak M, Thogersen HC, Edwards PC, Runswick MJ, Jakes R, Walker JE, Milstein C, Roth M, Klug A (1988) Isolation of a fragment of tau derived from the core of the paired helical filament of Alzheimer disease. Proc Natl Acad Sci U S A 85: 4506-4510

Witman GB, Cleveland DW, Weingarten MD, Kirschner MW (1976) Tubulin requires tau for growth onto microtubule initiating sites. Proc Natl Acad Sci U S A 73:4070-4074

Witte H, Neukirchen D, Bradke F (2008) Microtubule stabilization specifies initial neuronal polarization. J Cell Biol 180:619-632

Yu WH, Fraser PE (2001) S100beta interaction with tau is promoted by zinc and inhibited by hyperphosphorylation in Alzheimer's disease. J Neurosci 21:2240-2246

Yuan A, Kumar A, Peterhoff CM, Duff KE, Nixon RA (2008) Axonal transport rates in vivo are unaffected by tau deletion or overexpression in mice. J Neurosci 28:1682-1687

Zamostiano R, Pinhasov A, Gelber E, Steingart RA, Seroussi E, Giladi E, Bassan M, Wollman Y, Eyre HJ, Mulley JC, Brenneman DE, Gozes I (2001) Cloning and characterization of the human activity-dependent neuroprotective protein. J Biol Chem 276:708-714 
Zemlyak I, Sapolsky R, Gozes I (2009) NAP protects against cytochrome $\mathrm{c}$ release: inhibition of the initiation of apoptosis. Eur $\mathrm{J}$ Pharmacol 618:9-14

Zempel H, Thies E, Mandelkow E, Mandelkow E-M (2010) Abeta oligomers cause localized $\mathrm{Ca}(2+)$ elevation, missorting of endogenous Tau into dendrites, Tau phosphorylation, and destruction of microtubules and spines. J Neurosci 30:11938-11950
Zhang B, Maiti A, Shively S, Lakhani F, McDonald-Jones G, Bruce J, Lee EB, Xie SX, Joyce S, Li C, Toleikis PM, Lee VM-Y, Trojanowski JQ (2005) Microtubule-binding drugs offset tau sequestration by stabilizing microtubules and reversing fast axonal transport deficits in a tauopathy model. Proc Natl Acad Sci U S A 102:227-231 